\title{
PENGARUH KEPUASAN KERJA DAN MOTIVASI BERPRESTASI TERHADAP KINERJA MANAJERIAL DIMEDIASI KOMITMEN AFEKTIF PADA KEJAKSAAN TINGGI WILAYAH KALIMANTAN TIMUR
}

\author{
Adhitia Ferdinand Ideris $^{1}$, Tetra Hidayati $^{2}$, Ariesta Heksarini ${ }^{3}$ \\ Universitas Mulawarman Samarinda \\ Email : adhitiaf1@gmail.com ${ }^{1}$, tetra.hidayati@feb.unmul.ac.id ${ }^{2}$, \\ ariesta.heksarini@feb.unmul.ac.id ${ }^{3}$
}

\begin{abstract}
ABSTRAK
Tujuan penelitian ini adalah untuk menguji pengaruh antara kepuasan kerja dan motivasi berprestasi terhadap kinerja manajerial dengan komitmen afektif sebagai variabel intervening pada Kejaksaan Tinggi Wilayah Kalimantan Timur. Penelitian ini tergolong penelitian kuantitatif yang diharapkan dapat mengukur pengaruh antar variabel. Pengumpulan data dilakukan menggunakan kuesioner dengan tehnik sampling adalah sample jenuh, sebanyak 60 responden. Pengolahan data dilakukan dengan menggunakan SEM (Structural Equation Modelling). Hasil penelitian ini menunjukkan bahwa kepuasan kerja, motivasi berprestasi dan komitmen afektif masing-masing berpengaruh positif signifikan terhadap kinerja manajerial. Hasil analisis juga menunjukkan bahwa komitmen afektif memediasi pengaruh tidak langsung antara kepuasan kerja dan motivasi berprestasi terhadap kinerja manajerial dengan sifat mediasi parsial. Makna dari penelitian ini adalah bahwa semakin baik kepuasan kerja pegawai dan semakin tinggi motivasi berprestasi pegawai maka semakin tinggi komitmen afektif yang selanjutnya akan meningkatkan kinerja pegawai.
\end{abstract}

Kata Kunci : Kepuasan Kerja, Motivasi Berprestasi, Komitmen Afektif, Kinerja Manajerial

\begin{abstract}
The purpose of this study is to test the influence between job satisfaction and motivation of achievement on managerial performance with affective commitment as an intervening variable in Kejaksaan Tinggi Kalimantan Timur area. This research is classified as quantitative research that is expected to measure the influence between variables. Data collection was conducted using questionnaires with sampling techniques are saturated samples, as many as 60 respondents. Data processing is done using SEM (Structural Equation Modelling). The results of this study showed that job satisfaction, performance motivation and affective commitment each had a significant positive effect on managerial performance. The results of the analysis also showed that affective commitment mediates the indirect influence between job satisfaction and the motivation of achievement on managerial performance and the nature of partial mediation. The meaning of this research is that the better employee job satisfaction and the higher the motivation of employee achievement, the higher the affective commitment that will further improve employee performance.
\end{abstract}

Keywords: job satisfaction, motivation of achievement, affective commitment, managerial performance

\section{PENDAHULUAN}

Keberhasilan suatu organisasi sangat erat kaitannya dengan kualitas kinerja manajerial para anggotanya, sehingga organisasi dituntut untuk selalu mengembangkan dan meningkatan kinerja manajerial dari para anggotanya. Kinerja manajerial yang tinggi akan mendukung produktivitas organisasi, sehingga sudah seharusnya pimpinan organisasi senantiasa memperhatikan peningkatan kinerja manajerial demi kemajuan organisasi. 
Manajer dalam suatu organisasi memiliki peran dan fungsi dalam mengelola dan mengendalikan kinerja organisasi. Peran seorang manajer yaitu membuat rencana jangka pendek ataupun jangka panjang, mengontrol aktivitas kerja dan aktivitas manajemen lainnya untuk mencapai suatu tujuan bersama. Keberhasilan manajer di suatu organisasi akan dilihat dari hasil kinerja manajerialnya.

Pada instansi pemerintahan atau lembaga negara, manajer bisa disamakan dengan pimpinan yang membawahi beberapa staf dibawahnya tergantung jabtan dan bidang yang dipimpinnya. Pada lembaga Kejaksaan Tinggi Wilayah Kalimantan Timur kinerja manajerial diharapkan bisa memberikan gambaran bagaiaman para pimpinan bekerja sesuai dengan prosedur dan tata tertib yang telah ditetapkan. Pencapaian kinerja yang tinggi bagi aparatur yang bekerja di lingkungan Kejaksaan Tinggi Wilayah Kalimantan Timur merupakan cerminan keberhasilan lembaga tersebut dalam melayani masyarakat dalam bidang penegakan hukum.

Kepuasan kerja merupakan sesuatu yang bersifat individual, dimana setiap individual memiliki tingkat kepuasan yang berbeda-beda sesuai dengan sistem yang berlaku pada dirinya Ketika semakin banyak aspek dalam pekerjaan yang sesuai dengan keinginan individu, maka akan semakin tinggi kepuasan yang dirasakan. Kepuasan kerja adalah sikap emosional yang menyenangkan dan mencintai pekerjaannya. Sikap ini dicerminkan oleh moral kerja, kedisiplinan, dan prestasi kerja. Kepuasan kerja dinikmati dalam pekerjaannya dan diluar pekerjaannya.

Manajer yang memiliki kepuasan kerja, cenderung akan lebih produktif memberikan kontribusi terhadap tujuan organisasi. Justru sebaliknya, apabila manajer mengalami ketidakpuasan kerja akan menyebabkan hasil kerja yang tidak diinginkan yang menyebabkan kinerja pegawai menurun dan tidak sesuai harapan. Pengaruhnya terhadap kinerja menejerial menurun, maka tugas-tugas yang sudah ditetapkan akan menjadi terhambat, berakibat pada tidak tercapainya target pekerjaan unit atau bagian secara keseluruhan.

Agar kinerja Aparatur negara di lingkungan Kejaksaan Tinggi Wilayah Kalimantan Timur tetap terjaga pada standar yang telah ditetapkan perlu didukung dengan banyak faktor. Salah satu faktornya adalah kepuasan kerja bagi aparatur yang bekerja di lingkungan Kejaksaan Tinggi Wilayah Kalimantan Timur. Jika aparatur memiliki kepuasan kerja yang tinggi maka diharapkan akan memberikan kontribusi yang besar terhadap pencapaian tujuan dari lembaga Kejaksaan Tinggi Wilayah Kalimantan Timur. Mereka akan lebih giat bekerja dan berkomitmen tinggi terhadap organisasinya.

Motivasi yang terdapat dalam diri individu dianggap sederhana dan dapat pula menjadi masalah yang kompleks. Namun memotivasi seseorang merupakan hal yang sangat sulit. Hal ini karena sulit untuk mengetahui kebutuhan (needs) dan keinginan (wants) yang diperlukan individu dari hasil pekerjaannya. Motivasi berprestasi yang dimiliki seorang manajer memiliki peranan yang penting bagi kemajuan suatu organisasi, karena ketika seorang manajer memiliki dorongan yang kuat untuk berprestasi maka akan tumbuh suatu usaha untuk mencapai prestasi tersebut.

Kinerja manajerial akan menjadi tinggi, apabila adanya dorongan motivasi. Begitu sebaliknya, apabila seorang manajer tidak didorong dengan motivasi akan mengakibatkan kinerja manajerial yang buruk. Dengan adanya motivasi kerja maka dapat lebih mudah dalam mengapai kinerja yang diharapkan dalam oraganisasi tersebut sehingga terdapat kepuasaan kerja dalam pencapaian kinerja yang baik.

Dengan demikian kualitas dan kuantitas manajer yang kurang baik akan berdampak pada kinerja manajerial yang kurang baik, diperburuk dengan rendahnya komitmen yang dimiliki seorang manajer serta kurangnya motivasi yang dimiliki manajer untuk mendorong kinerja yang baik. Pada umumnya kondisi ini disebabkan kurangnya kepuasan kerja yang dimiliki manajer sehingga memperburuk pada kinerja manajerial. Untuk itu organisasi harus mengetahui faktor-faktor yang mempengaruhi 
kinerja manajerial. Sehingga manajer nantinya dapat menghasilkan dan meningkatkan kinerja manajerial dengan lebih efektif.

Adanya suatu komitmen afektif dalam diri individu dapat menjadi sebagai penggerak individu dalam bekerja dan dapat menjadi dorongan bagi individu untuk bekerja lebih baik. Komitmen seorang manajer terhadap visi, tujuan organisasi dan kesadaran diri atas tugas dan tanggun g jawab membantu untuk efektivitas organisasi. Manajer yang berkomitmen memiliki rasa integritas pribadi dan kepercayaan diri yang kuat.

Mereka yang mempunyai komitmen kelanjutan yang kuat akan bertahan di organisasi karena mereka merasakan bahwa keinginan untuk melakukannya di dorong oleh kebutuhan atau tidak adanya pekerjaan lain, secara normatif, mengikat pegawai karena mereka merasakan bahwa mereka hendaknya melakukan apa yang telah menjadi arah tujuan organisasi itu sendiri.

Penelitian yang dilakukan oleh Apriansyah et al., menunjukkan kepuasan kerja tidak berpengaruh terhadap kinerja manajerial pada perhotelan di Provinsi Riau [1]. Hal ini disebabkan karena ada rasa ketidakpuasan terhadap pekerjaan pada organisasi tersebut. Sedangkan pada penelitian Sari et al., menunjukkan kepuasan kerja berpengaruh positif terhadap kinerja manajerial Kejaksaan Negeri Wilayah Aceh[2].

Penelitian yang dilakukan oleh Butar Butar et al., menunujukan bahwa motivasi berprestasi berpengaruh positif tetapi tidak signifikan terhadap kinerja pegawai pada Pegawai Dinas Pekerjaan Umum, Penataan Ruang dan Perumahan Rakyat Provinsi Kalimantan Timur[3]. Sedangkan pada penelitian Rohayati, menunjukan hasil bahwa motivasi berprestasi berpengaruh positif signifikan terhadap kinerja kinerja manajerial kepala sekolah di Cisalengka[4].

Dari hasil penelitian-penelitan tersebut diatas terdapat inkonsistensi hasil penelitan yang mejadi kesenjangan penelitian yang memberikan ruang bagi peneliti untuk mengisi kesenjangan tersebut dalam penelitian ini pada lingkungan Kejaksaan Tinggi Wilayah Kalimantan Timur.

Kantor Kejaksaan Tinggi Wilayah Kalimantan Timur yang berdomisili di Kota Samarinda juga merupakan organisasi yang terdiri dari orang-orang yang bekerja pada lembaga negara tersebut. Sebagai salah satu lembaga negara tentu dituntut untuk berkinerja baik dalam memberikan pelayanan kepada masyarakat. Kinerja dan pelayanan masyarakat pada lembaga negara tidak terlepas dari kinerja para pegawainya dari berbagai level.

Bekerja pada masa pendemi merupakan tantangan bagi para pimpinan di Kejaksaan Tinggi Wilayah Kalimantan Timur karena sebagian pegawai harus melakukan pekerjaan di rumah atau work fom home sebagai upaya menekan penyebaran virus Covid 19. Pembatasan jumlah pegawai di ruangan kantor memaksa pimpinan melakukan penyesuaian dalam penerapan fungsi manajemen yaitu plan, organizing, actuiting dan controling.

\section{LANDASAN TEORI \\ Kinerja Manajerial}

Secara tradisional, istilah manajemen kinerja telah didefinisikan sebagai aplikasi proses sistematis manajemen yang bertujuan untuk mengoptimalkan kinerja manusia dalam suatu organisasi. Kinerja manajerial didefinisikan sebagai pengetahuan manajemen, yang dianggap mencerminkan keterampilan dan pengetahuan khusus manajemen, tanpa memperhatikan jenis bisnisnya. Kinerja manajerial adalah sistem pengukuran bekerja sama dengan mengukur efisiensi pelaksanaan suatu program atau layanan oleh organisasi, yang dilakukan sistematis dengan prosedur yang tepat [5].

Kinerja manajerial mengarah pada kinerja ekonomi, keuangan dan sumber daya manusia yang merupakan sumber daya terpenting dari sebuah organisasi [6]. Kinerja 
manajerial dihasilkan dan dicapai pada tingkat manajer, yaitu pada tingkat orang yang menjalankan proses manajemen (perencanaan, pengorganisasian, koordinasi, pelatihan, kontrol dan evaluasi).

\section{Kepuasan kerja}

Kepuasan kerja (job statisfaction) pegawai harus diciptakan sebaik-baiknya supaya moral kerja, dedikasi, kecintaan, dan kedisiplinan pegawai meningkat. Kepuasan kerja dalam pekerjaan adalah kepuasan kerja yang dinikmati dalam pekerjaan dengan memperoleh pujian hasil kerja, penempatan, perlakuan, peralatan, dan suasana lingkungan kerja yang baik. Sikap umum terhadap pekerjaan seseorang yang menunjukkan perbedaan antara jumlah penghargaan yang diterima pegawai dan jumlah yang mereka yakini seharusnya mereka terima [7].

Kepuasan kerja merupakan orientasi emosi yang dimiliki karyawan terhadap peran yang mereka lakukan di tempat kerja dan merupakan komponen penting untuk motivasi dan dorongan karyawan menuju kinerja yang lebih baik [8]. Kepuasan kerja adalah atribut psikologis dari karyawan yang dia nikmati dan merupakan faktor yang paling penting dalam memahami motivasi pekerja,efektivitas, retensi dan kinerja [9].

\section{Motivasi Berprestasi}

Motivasi berprestasi adalah dorongan kekuatan pribadi seseorang yang ingin melakukan sesuatu yang terbaik, terpuji, dan berguna bagi orang lain secara inovatif, kreatif, dan tekun memiliki tanggung jawab yang tinggi terhadap tugasnya, kerja keras dan tekun, menyukai tantangan, dan berani mengambil risiko. SDM yang memiliki motivasi berprestasi adalah manusia-manusia unggul yang dapat mengatasi persoalan-persoalan yang dihadapinya baik terikat dengan diri sendiri, keluarga, masyarakat, dan bangsanya [10].

Motivasi berprestasi adalah usaha dan keyakinan individu untuk mewujudkan tujuan belajar dengan standar keberhasilan tertentu dan mampu mengatasi segala rintangan yang menghambat pencapaian tujuan. Motivasi berprestasi merupakan kebutuhan menyelesaikan hal sulit, menguasai, mengungguli, menandingi, dan melampui individu lain serta memgatasi hambatan dan mencapai standar yang tinggi.

\section{Komitmen Afektif}

Komitmen afektif merupakan derajat dimana seorang pegawai mengidentifikasi dirinya dengan organisasi tertentu beserta tujuan dan berkeinginan untuk mempertahankan keanggotannya dalam organisasi tersebut. Hal ini menunjukkan bahwa pegawai yang memiliki komitmen yang tinggi terhadap organisasi akan melakukan tidak hanya tugas-tugas yang telah menjadi kewajibannya, tetapi dengan sukarela akan mengerjakan hal-hal yang dapat digolongkan sebagai usaha-usaha ekstra (extra effort).

Komitmen afektif merupakan bentuk emosi pegawai seperti identifikasi dan keterlibatan pada organisasi [11,12]. Affective commitment adalah suatu hubungan yang kuat antara individu dengan perusahaan yang diidentifikasikan dengan keikutsertaannya dalam kegiatan perusahaan atau organisasi. Komitmen afektif merupakan keterkaitan emosi pada organisasi dan suatu kepercayaan terhadap nilainilainya. Seorang pegawai mungkin akan tetap peduli pada organisasi karena organisasi tersebut peduli dengan lingkungan seperti yang disukainya.

Komitmen ini mendorong orang-orang ingin terus bekerja untuk organisasi tersebut karena mereka sependapat dengan tujuan dan nilai dalam organisasi tersebut. Orang-orang dengan tingkat komitmen afektif yang tinggi memiliki keinginan untuk tetap berada di organisasi karena mendukung tujuan dari organisasi tersebut dan bersedia membantu untuk mencapai tujuan tersebut. Komitmen afektif merupakan bentuk emosi pegawai seperti identifikasi dan keterlibatan pada organisasi $[13,14]$. 


\section{METODOLOGI PENELITIAN}

Penelitian kuantitatif ini dapat dikategorikan sebagai penelitian explanatory yang menjelaskan kedudukan konstruk-konstruk yang diteliti serta hubungan antara konstruk satu dengan konstruk lainnya atau penelitian yang menjelaskan hubungan antara variabel-variabel penelitian dan pengujian hipotesis yang telah dirumuskan sebelumnya.

Teknik pengumpulan data dalam penelitian ini adalah Kuesioner yang dilakukan dengan cara memberikan seperangkat pertanyaan atau pernyataan tertulis kepada responden untuk dijawabnya. Populasi dalam penelitian ini adalah Aparatur Sipil Negara di lingkungan Kejaksaan Tinggi Wilayah Kalimantan Timur. Dalam penelitian ini teknik sampling yang digunakan yaitu nonprobability sampling dengan teknik purposive sampling. Dari kriteria diperoleh sampel sebanyak 60 responden.

Model penelitian yang akan digunakan dalam penelitian ini adalah model struktur berjenjang dan untuk menguji hipotesis yang diajukan digunakan teknik analisis SEM (Structural Equation Modelling) dengan menggunakan program Smart PLS (Partisal Least Square). Permodelan melalui SEM juga memungkinkan seorang peneliti dapat menjawab pertanyaan penelitian yang bersifat regresif maupun dimensional.

\section{HASIL PENELITIAN DAN PEMBAHASAN}

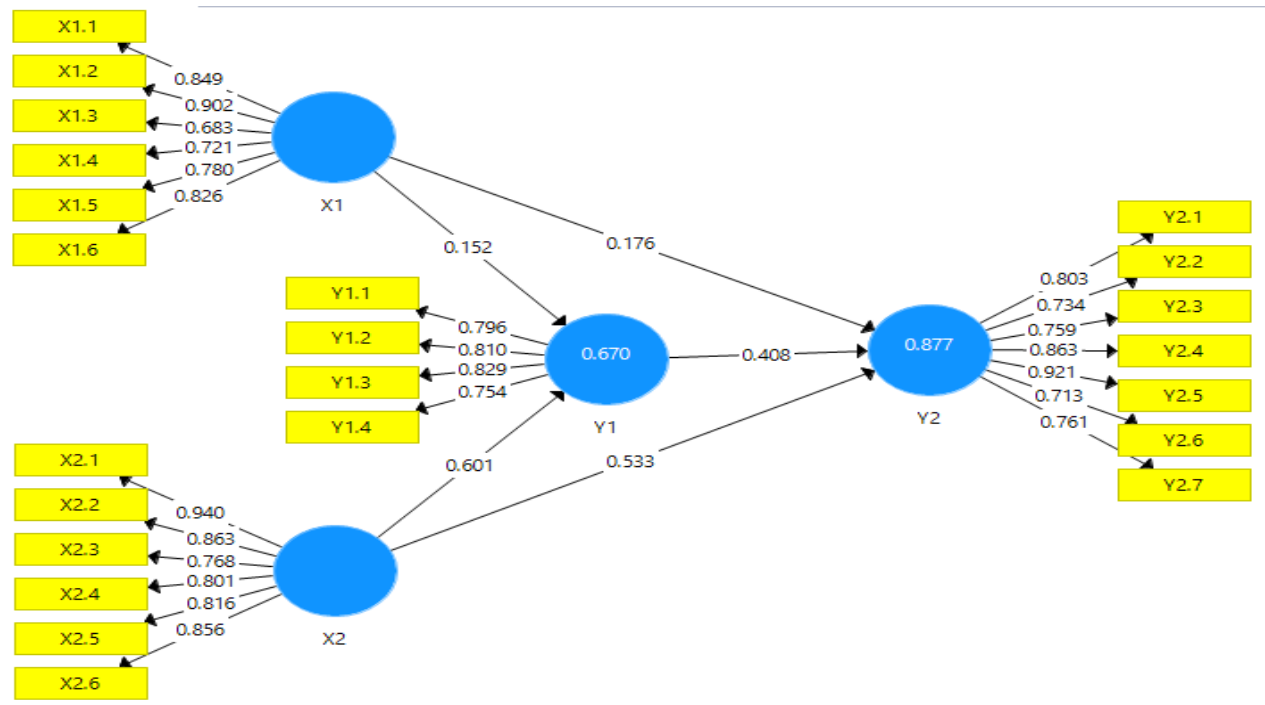

Sumber : Olah data SmartPLS (2021)

Gambar 1. Outer Model

Tabel 1. Validitas, Reabilitas dan $\mathbf{R}^{2}$

\begin{tabular}{lccccc}
\hline \multicolumn{1}{c}{ Variabel } & $\boldsymbol{A V E}$ & $\sqrt{ } \boldsymbol{A V E}$ & $\begin{array}{c}\text { Composite } \\
\text { Reliability }\end{array}$ & $\begin{array}{c}\text { Cronbachs } \\
\text { Alpha }\end{array}$ & $\begin{array}{c}\boldsymbol{R} \\
\text { Square }\end{array}$ \\
\hline Kinerja Manajerial $\left(\mathrm{Y}_{2}\right)$ & 0.634 & 0.796 & 0.923 & 0.902 & 0.877 \\
Komitmen Afektif $\left(\mathrm{Y}_{1}\right)$ & 0.636 & 0.798 & 0.875 & 0.809 & 0.670 \\
Motivasi Berprestasi $\left(\mathrm{X}_{2}\right)$ & 0.710 & 0.842 & 0.936 & 0.917 & \\
Kepuasan Kerja $\left(\mathrm{X}_{1}\right)$ & 0.635 & 0.797 & 0.912 & 0.883 & \\
\hline
\end{tabular}

Sumber: Data diolah (2021)

Dari Tabel 1 diketahui bahwa nilai AVE masing-masing konstruk berada di atas 0,5 . Oleh karenanya tidak ada permasalahan convergen validity pada model yang diuji sehingga konstruk dalam model penelitian ini dapat dikatakan memiliki validitas diskriminan yang baik. Setelah diketahui nilai akar kuadrat dari AVE, tahap selanjutnya adalah membandingkan akar kuadrat AVE masing-masing konstruk dengan korelasi 
antar konstruk dalam model. Berdasarkan pada tabel 1 menunjukkan bahwa nilai akar kuadrat AVE untuk masing-masing konstruk lebih besar daripada nilai korelasinya sehingga konstruk dalam model penelitian ini masih dapat dikatakan memiliki discriminant validity yang baik. Nilai composite reliability dan cronbachs alpha semua variabel $>0.7$ sehingga telah memenuhi uji reliabilitas yang selanjutnya semua variabel dapat digunakan untuk melalukan uji hipotesis.

Berdasarkan pada tabel 1 nilai $\mathrm{R}^{2}$ untuk variabel dependent kinerja manajerial sebesar 0,877 berarti bahwa $87,7 \%$ perubahan kinerja manajerial dipengaruhi oleh kepuasan kerja, motivasi berprestasi dan komitmen afektif sedangkan sisanya sebesar $12,3 \%$ dipengaruhi oleh variabel lain yang tidak di bahas di penelitian ini. Nilai $\mathrm{R}^{2}$ untuk variabel dependent komitmen afektif sebesar 0,670 , berarti bahwa $67 \%$ perubahan variabel komitmen afektif dipengaruhi oleh variabel independent Kepuasan Kerja dan motivasi berprestasi sedangkan sisanya sebesar 33\% dipengaruhi oleh variabel lain yang tidak di bahas di penelitian ini.

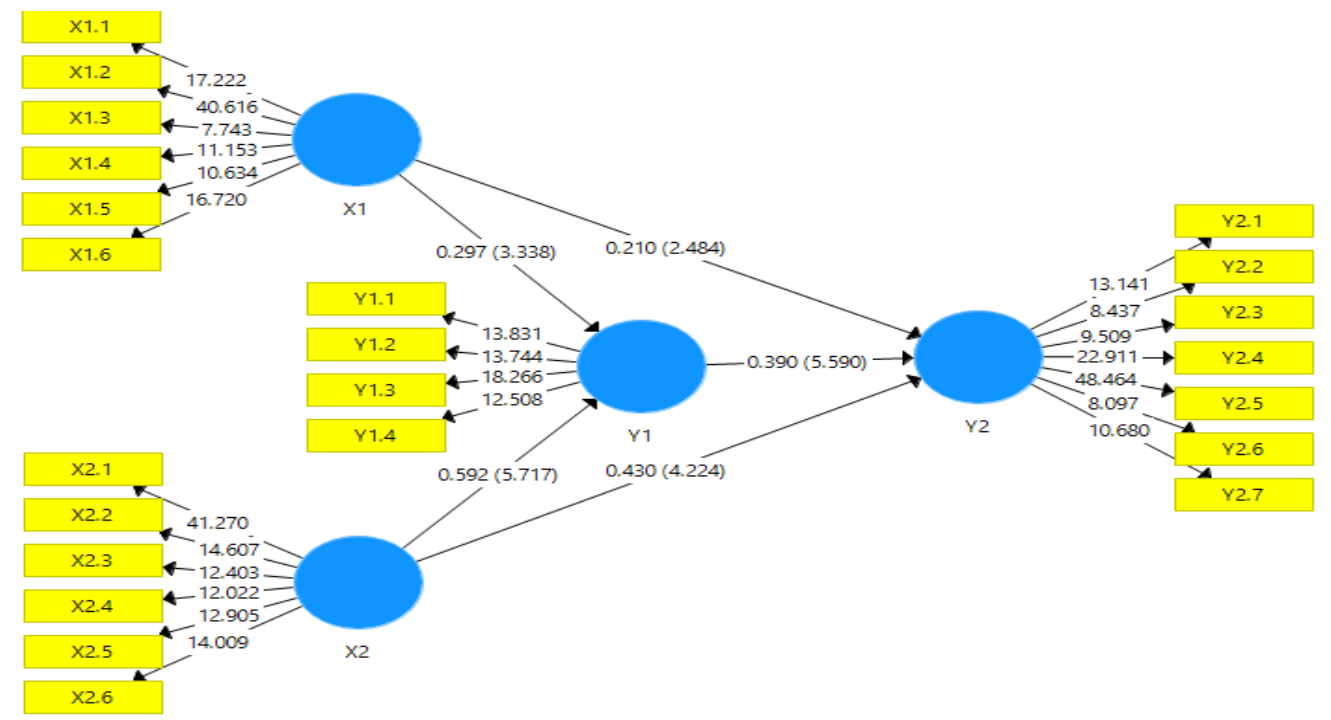

Sumber : Olah data SmartPLS

Gambar 2. Full Model Bootrapping

Tabel 2. Path Coeffecients

\begin{tabular}{|c|c|c|c|c|c|c|}
\hline $\begin{array}{c}\text { Hubungan } \\
\text { Antar Variabel }\end{array}$ & $\begin{array}{c}\text { Original } \\
\text { Sample } \\
(\mathrm{O})\end{array}$ & $\begin{array}{c}\text { Sample } \\
\text { Mean } \\
(\mathrm{M})\end{array}$ & $\begin{array}{l}\text { Standard } \\
\text { Deviation } \\
\text { (STDEV) }\end{array}$ & $\begin{array}{c}\text { T Statistics } \\
(|\mathrm{O} / \mathrm{STERR}|)\end{array}$ & $P$ Value & Ket. \\
\hline $\mathrm{X}_{1} \rightarrow \mathrm{Y}_{1}$ & 0,297 & 0,303 & 0,085 & 3,502 & 0,000 & Sig. \\
\hline$X_{1}->Y_{2}$ & 0,210 & 0,215 & 0,087 & 2,414 & 0,016 & Sig. \\
\hline$X_{2}->Y_{1}$ & 0,592 & 0,587 & 0,102 & 5,823 & 0,000 & Sig. \\
\hline$X_{2}->Y_{2}$ & 0,430 & 0,435 & 0,104 & 4,123 & 0,000 & Sig. \\
\hline$Y_{1} \rightarrow Y_{2}$ & 0,390 & 0,380 & 0,072 & 5,427 & 0,000 & Sig. \\
\hline$X_{1} \rightarrow Y_{1} \rightarrow Y_{2}$ & 0,116 & 0,116 & 0,040 & 2,933 & 0,004 & Sig. \\
\hline$X_{2} \rightarrow Y_{1} \rightarrow Y_{2}$ & 0,231 & 0,228 & 0,060 & 3,874 & 0,000 & Sig. \\
\hline
\end{tabular}

Sumber: Data diolah (2021)

Berdasarkan pada tabel 2 nilai koefisien pengaruh antara kepuasan kerja terhadap kinerja manajerial adalah positif yaitu sebesar 0,210 yang menunjukkan bahwa arah hubungan antara kepuasan kerja dengan kinerja manajerial adalah positif. Nilai t hitung sebesar 2,414 $>2,003$ dengan tingkat signifikasi $5 \%$ dan nilai $\mathrm{df}=56$, berarti signifikan dan hubungannya positif. Nilai t hitung lebih besar dari t tabel maka hipotesis pertama 
(H1) terbukti kebenarannya dan diterima, yang berarti bahwa peningkatan kepuasan kerja diharapkan dapat meningkatkan kinerja manajerial.

Nilai koefisien pengaruh antara motivasi berprestasi terhadap kinerja manajerial adalah positif yaitu sebesar 0,430 yang menunjukkan bahwa arah hubungan antara motivasi berprestasi dengan kinerja manajerial adalah positif. Nilai $t$ hitung sebesar $4,123>2,003$ lebih besar dari t tabel maka hipotesis kedua $(\mathrm{H} 2)$ terbukti kebenarannya dan diterima, yang berarti bahwa peningkatan motivasi berprestasi diharapkan dapat meningkatkan kinerja manajerial.

Nilai koefisien pengaruh kepuasan kerja terhadap komitmen afektif adalah positif yaitu sebesar 0,297 yang menunjukkan bahwa arah hubungan antara kepuasan kerja dengan komitmen afektif adalah positif. Nilai t statistik 3,503 >2,003 lebih besar dari $t$ tabel maka hipotesis ketiga (H3) terbukti kebenarannya dan diterima, yang berarti bahwa peningkatan kepuasan kerja diharapkan dapat meningkatkan komitmen afektif.

Nilai koefisien pengaruh motivasi berprestasi terhadap komitmen afektif adalah positif yaitu sebesar 0,592 yang menunjukkan bahwa arah hubungan antara motivasi berprestasi dengan komitmen afektif adalah positif. Nilai t hitung 5,823 > 2,003 lebih besar dari t tabel maka hipotesis ke empat $(\mathrm{H} 4)$ terbukti kebenarannya dan diterima, yang berarti bahwa peningkatan motivasi berprestasi diharapkan dapat meningkatkan komitmen afektif. Nilai koefisien pengaruh komitmen afektif terhadap kinerja manajerial adalah positif yaitu sebesar 0,390 yang menunjukkan bahwa arah hubungan antara komitmen afektif dengan kinerja manajerial adalah positif. Nilai t hitung sebesar 5,427 $>2,003$ lebih besar dari t tabel maka hipotesis kelima (H5) terbukti kebenarannya dan diterima, yang berarti bahwa peningkatan komitmen afektif diharapkan dapat meningkatkan kinerja manajerial.

Berdasarkan tabel 2 maka dapat dicari nilai VAF (variance account for) Hair et al., adalah sebesar 0,356 masih pada kisaran nilai 0,2 - 0,8 [12], berarti komitmen afektif adalah variabel yang memediasi pengaruh antara kepuasan kerja dengan kinerja manajerial dengan sifat mediasi adalah mediasi parsial. Mediasi parsial adalah mediasi dimana pengaruh variabel independent terhadap variabel dependent masih tetap signifikan pada saat variabel intervening atau variabel mediasi dimasukkan dalam model. Setelah komitmen afektif dimasukkan sebagai variabel intervening terjadi penurunan koefeisen kepuasan kerja terhadap kinerja manajerial yaitu dari 210 menjadi 116 dan nilai t hitung menurun dari 2,414 menjadi 2,933. Meski terjadi penurunan nilai koefeisen dan $t$ hitung masih meunjukkan hubungan positif dan signifikan yang menunjukan bahwa komitmen afektif mampu menjadi variabel mediasi yang dapat meningkatkan secara tidak langsung pengaruh kepuasan kerja dengan kinerja manajerial. Maka hipotesis keenam (H6) terbukti kebenarannya dan diterima.

Pengujian hipotesis ketujuh $(\mathrm{H} 7)$ untuk menentukan apakah komitmen afektif sebagai variabel mediasi atau tidak digunakan metode VAF (variance account for). Berdasarkan tabel 2 maka dapat dicari nilai VAF adalah sebesar 0,348 berada pada kisaran nilai 0,2 - 0,8 sehingga bisa disimpulkan bahwa komitmen afektif merupakan variabel yang memediasi pengaruh antara motivasi berprestasi dengan kinerja manajerial, dengan sifat mediasi adalah mediasi parsial Maka hipotesis ketujuh (H7) terbukti kebenarannya dan diterima.

Setelah komitmen afektif dimasukkan sebagai variabel intervening terjadi penurunan koefeisen motivasi berprestasi terhadap kinerja manajerial yaitu dari 430 menjadi 231 dan nilai t hitung menurun dari 4,123 menjadi 3,874. Meski terjadi penurunan nilai koefeisen dan $t$ hitung masih meunjukkan hubungan positif dan signifikan yang menunjukan bahwa komitmen afektif mampu menjadi variabel mediasi yang dapat meningkatkan secara tidak langsung pengaruh motivasi berprestasi dengan kinerja manajerial. 


\section{KESIMPULAN DAN SARAN}

Indikator dari kepuasan kerja yang dominan mempengaruhi kinerja manajerial adalah pekerjaan itu sendiri yang berarti pekerjaan sebagai ASN di lingkungan Kejaksaan Tinggi Kalimantan Timur dapat meningkatkan kepuasan pegawai. Indikator dari motivasi berprestasi yang dominan mempengaruhi kinerja manajerial adalah keinginan yang kuat untuk mencapai tujuan yang bermakna bahwa pegawai memiliki motivasi yang kuat untuk berprestasi. Indikator dari komitmen afektif yang dominan mempengaruhi kinerja manajerial adalah rasa memiliki yang kuat terhadap organisasi yang bermakna bahwa kinerja manajerial sangat dipengaruhi oleh rasa memiliki terhadap organisasi yang kuat.

Jika ingin meningkatkan kinerja manajerial makan hendaknya Kejaksaan Tinggi Wilayah Kalimantan Timur memprioritaskan pada pekerjaan pegawai sehingga pegawai merasa berarti dalam organisasi tempat bekerja dan pada keinginan yang kuat untuk mencapai tujuan sehingga pegawai memiliki saluran dan peluang untuk berbuat yang terbaik untuk organisasi.

\section{DAFTAR PUSTAKA}

[1] Apriansyah, G., Zirman, \& Rusli. (2014). Pengaruh Partisipasi Anggaran, Komitmen Organisasi, Kepuasan Kerja, Job Relevant Information dan Budaya Organisasi Terhadap Kinerja Manajerial pada Perhotelan di Provinsi Riau. Jom Fekon, 1(2), 1-22.

[2] Sari, D. W., Arfan, M., \& Abdullah, S. (2017). Pengaruh Partisipasi Penyusunan Anggaran, Kepuasan Kerja, Job Relevant Information Dan Motivasi Kerja Terhadap Kinerja Manajerial Kejaksaan Negeri Wilayah Aceh. Jurnal Megister Akuntansi Pascasarjana Universitas Syiah Kuala, 6(17), 20-31.

[3] Butar Butar, J., Hidayati, T., \& Zainurrossalamia, S. (2020a). Ilmu Sosial dan Pendidikan. Jurnal IImu Sosialndan Pendidikan, 1. https://doi.org/http://dx.doi.org/10.36418/syntax-imperatif.v1i3.35

[4] Rohayati, T. (2014a). Pengaruh Komitmen dan Motivasi Berprestasi terhadap Kinerja Manajerial Kepala Sekolah Dasar Negeri di Kecamatan Cicalengka. Jurnal Administrasi Pendidikan, 21(1), 1-10.

[5] Sanusi, A., \& Septarina, L. (2016). Managerial Performance Model of Private Higher Education in The South Sumatra. 6th International Conference on Educational, Management, Administration and Leadership (ICEMAL2016), 14(1), 138-144. http://creativecommons.org/licenses/by-nc/4.0/

[6] Muscalu, E. (2016). Managerial Performance and Its Influenceing Factors Nowadays. Revista Economică University of Sibiu, Romania, 6, 91-103. http://economice.ulbsibiu.ro/revista.economica/archive/68608muscalu.pdf

[7] Afandi, P. (2016). Concept \& Indicator Human Resources Management for Management Research. Deepublish.

[8] Raziq, A., \& Maulabakhsh, R. (2015). Impact of Working Environment on Job Satisfaction. Procedia Economics and Finance, 23(October 2014), 717-725. https://doi.org/10.1016/S2212-5671(15)00524-9

[9] Shaju, M., \& Subhashini, D. (2017). A study on the impact of Job Satisfaction on Job Performance of Employees working in Automobile Industry, Punjab, India. Journal of Management Research, 9(1). https://doi.org/10.5296/jmr.v9i1.10420

[10] Sagala, S. (2017). Human Capital: Membangun Modal Sumber Daya Manusia Berkarakter Unggul Melalui Pendidikan Berkualitas. Kencana.

[11] Shaleh, M. (2018). Komitmen Organisasi terhadap Kinerja Pegawai. Aksara Timur. 
[12] Joseph F. Hair, J., Hult, G. T. M., Ringle, C. M., \& Sarstedt, M. (2014). A Primer on Partial Least Squares Structural Equation Modeling (PLS-SEM) (second Edi). SAGE Publications, Inc. https://doi.org/10.1007/s10995-012-1023-x [doi]

[13] Emiyanti, L., Rochaida, E., \& Tricahyadinata, I. (2020). Pengaruh Karakteristik Individu Dan Motivasi Intrinsik Terhadap Komitmen Afektif Dan Kinerja Pegawai. The Manager Review, 2(1).

[14] Soni, I. S. K. (2020). PERAN MOTIVASI INTRINSIK DALAM PENGARUH KOMITMEN AFEKTIF DAN KOMPETENSI TERHADAP KINERJA KARYAWAN DISABILITAS. Sains Manajemen, 6(2), 149-160. 